\title{
Use of Agency materials in broadsheet dailies of Nepal
}

\section{Introduction}

- Indra Dhoj Kshetri

The increase in broadsheet dailies in Nepal after the liberalization of media market in 1990s marked the change in the media content - a shift from earlier mission journalism to professionalism. Consequently, international news became the important feature of the dailies. Now, each Nepalese broadsheet daily has at least one page for the coverage of the international news obtained mainly through the news agencies: AP and AFP. In addition, large portion of sports, entertainment and biz stories come from these agencies. The corpus is enough to hint the importance of agency news.

However, the subject matter has attracted very few researchers in Nepal. Only two studies are found on foreign news coverage in Nepali media (Adhikary, 2002, December 11; Kshetri, 2006). Acknowledging Nepali media's effort to localize and present separate but related news stories on few instances, Adhikary observes, "the general trend in presenting international news in Nepali media is just copying news stories from international agencies." The latter study, based on one week's frequency and breadth of international news in Nepali broadsheet dailies (in a particular week after US invasion in Iraq), found that the news from there made almost $70 \%$ of the total coverage of the international news. In this study, I incorporate larger corpus and analyze the finding using the concept advanced by Franklin (2005), and discuss if the result, in anyway, can be taken as a prospect for McJournalism.

\section{Globalization and McJournalism}

The trend of international news coverage in the local media comes with globalization. "News", McQuail says "was the first media product to be effectively commodified for international

Bodhi, 3 (1), 44-52. ISSN 2091-0479. (C) 2009 Kathmandu University 
trade" (2005, p. 261). Arguing further, McQuail finds commodification responsible for standardization:

While earlier international 'foreign' news concentrated on politics, war, diplomacy and trade, there has been an enormous expansion of the scope for international news with particular reference to sport, the world of showbiz, finance, tourism, celebrity gossip, fashion and much more' (p. 262).

Show-biz and sports have been rampantly globalized for various purposes and these continue to constitute major portion of news coverage in all media.

Now, I bring insight from globalization theory to discuss whether the trend of covering agency materials is justified. Franklin (2005, p. 137-150), referring to Ritzer's McDonaldization has neologized a term, 'McJournalism' to signify the latest developments and patterns in the British press to equate with the globalized fast food culture known as McDonaldization. Franklin says that a trend of increasing use of standardized contents provided by the agencies or other sources including Public Relations firms by the British press is a symptom for the rise of Mcjournalism. He asserts that optimized use of and dependence on the agency materials will kill the quality and diversity of the journalism.

Using this theory, I examine if there is any prospect for such type of journalism rising in Nepali press. For the purpose of the study, I purposively chose four dailies: two English (The Kathmandu Post and The Himalayan Times) and two Nepali (Kantipur and Annapurna Post) language broadsheet dailies. And as the level of study did not permit the large sample, newspapers of a normal week - April 5-11, 2009 - was chosen for study. Content analysis is triangulated with qualitative method of in-depth interviews- people involved in the reproduction of these media contents were interviewed.

Bodhi, 3 (1), 44-52. ISSN 2091-0479. (C) 2009 Kathmandu University 


\section{Space for news and advertisements}

Mostly, broadsheet dailies appear in 12, 16 and 20 pages: Annapurna Post (AP) publishes in 16 broadsheet and 8 tabloid size pages; Kantipur (KP) publishes 20 pages in an average; The Kathmandu Post (TKP) has 14 pages average; The Himalayan Times (THT) publishes 16 pages. In terms of space availability for the advertisements and the news content, Nepali language KP carries the highest advertising space $(45 \%)$ in comparison to its sisterly publication TKP (19\%) while English language THT carries more advertisements (32\%) than its sisterly Nepali daily AP (22.5\%). The table below sums up the analysis.

\begin{tabular}{|c|c|c|c|c|}
\hline $\begin{array}{l}\text { Name of the } \\
\text { newspaper }\end{array}$ & & $\begin{array}{l}\text { total } \\
\text { pages }\end{array}$ & $\begin{array}{l}\text { Ad } \\
\text { space } \\
\text { (in qts) }\end{array}$ & $\begin{array}{l}\text { Ad space } \\
(\%)\end{array}$ \\
\hline \multirow[t]{4}{*}{ Kantipur } & Per day Average & 19.71 & 35.86 & 45.47 \\
\hline & Minimum & 16.00 & 22.00 & \\
\hline & Maximum & 22.00 & 44.00 & \\
\hline & Total in a week & 138.00 & 251.00 & \\
\hline \multirow[t]{4}{*}{$\begin{array}{l}\text { The Kathmandu } \\
\text { Post }\end{array}$} & Per day Average & 14.29 & 10.71 & 18.75 \\
\hline & Minimum & 12.00 & 6.00 & \\
\hline & Maximum & 20.00 & 22.00 & \\
\hline & Total in a week & 100.00 & 75.00 & \\
\hline \multirow[t]{4}{*}{ Annapurna Post } & Per day Average & 14.86 & 19.00 & 31.97 \\
\hline & Minimum & 12.00 & 12.00 & \\
\hline & Maximum & 20.00 & 26.00 & \\
\hline & Total in a week & 104.00 & 133.00 & \\
\hline \multirow[t]{4}{*}{$\begin{array}{l}\text { The } \\
\text { Himalayantimes }\end{array}$} & Per day Average & 14.29 & 14.43 & 25.25 \\
\hline & Minimum & 12.00 & 11.00 & \\
\hline & Maximum & 20.00 & 16.00 & \\
\hline & Total in a week & 100.00 & 101.00 & \\
\hline
\end{tabular}

Table 1: Number of pages and advertising space in broadsheet dailies of Nepal

Bodhi, 3 (1), 44-52. ISSN 2091-0479. (C) 2009 Kathmandu University 
For the measurement of the space for news, available space for news is calculated after reducing the advertisement space and counted out of that. There is almost similarity among these newspapers in the allocation of space for biz news (10.6$12.5 \%)$, sports (10-14\%) and International (5-7\%). TKP has allocated biggest space (14\%) for sports coverage while its sisterly publication KP gives lowest space $(10 \%)$. The largest difference is in the allocation of space for entertainment coverage with THT having highest (25.1\%) against the lowest by its sisterly AP $(6.25 \%)$.

\section{Use of original and agency contents}

The agency contents are measured after deducting original contents from the total space for news. The measurement was taken in cc (column per centimeters) and later converted into percentage of the total space. To have a wider perspective, the varieties sports, entertainment, international and biz have been counted separately. When aggregated, the result shows that newspapers use up to $30 \%$ agency materials of their total news space.

The study found that English language newspapers rely more on the agency materials than Nepali language papers, with highest reliance on entertainment and international news. Amongst four, TKP relies on the news agencies to fill in the largest space with $28.3 \%$ biz, $100 \%$ international, $72.4 \%$ sports and $53.6 \%$ entertainment. Nepali newspapers use least standardized contents in biz pages with KP 2.5\% and AP $20 \%$. English language newspapers use more agency materials for entertainment news - TKP $53.6 \%$ and THT $41.2 \%$. If we look at TKP alone, Biz, international, sports and entertainment make up $45 \%$ of the whole contents everyday. To calculate, it originally produces only $70 \%$ of the total content. KP uses the least standardized contents only $5 \%$ of the total followed by AP $(15 \%)$ and THT $(23 \%)$. The findings are presented below separately for different varieties of news.

Bodhi, 3 (1), 44-52. ISSN 2091-0479. (C) 2009 Kathmandu University 
Entertainment news: The study showed that English language newspapers give more space for entertainment coverage. TKP has a two-page CITY POST (p. 9-10) \& 1 page entertainment (p. 2). This makes the number of entertainment pages in an average day to 3 . THT carries 1 page POTPOURRI (either p. 2 or 4 ) with $25 \%$ original contents and $75 \%$ standardized contents everyday. It consists of movie details, cartoons, flight schedules, TV rundowns, crossword puzzles and messages. It has VARIETY in the last page which includes celebrity talk, horoscopes, crossword puzzles and jokes. Monday issue carries 2 pages of VARIETY. In an average day, it has 2 pages for entertainment while Monday has three and Friday has an additional TGIF supplement of four pages. On Monday, one whole page is filled with the items under 'author unknown', clearly indicating that they are collected from the internet sources. TKP's ENTERTAINMENT POST has similar contents as THT's POTPOURRI.

In Nepali language papers, AP has children's post on second page and its contents are mostly similar with the POTPOURRI and Kpost's ENTERTAINMENT POST; most of them standardized and received from internet mentioned under anonymous sources. Of the whole coverage of the entertainment news, THT uses $60.66 \%$ of agency materials in its entertainment coverage followed by TKP's $53.6 \%$.

Sports News: In an ordinary week day, all newspapers carry 2 page sports which go up to 3 or 4 pages in the weekends. Generally, one page is for domestic while the other is for international sports coverage. However, international sports news is sometimes given more importance than the domestic. The study week coincides with fifth national games which began on April 6. Despite the biggest national sports event, TKP has used $72.4 \%$ agency materials followed by KP's $28.1 \%$ and AP's $25.4 \%$ in their sports pages. Yet, inauguration ceremony, controversy over the participation of Maoist army in the games and major events and achievements are covered in

Bodhi, 3 (1), 44-52. ISSN 2091-0479. (C) 2009 Kathmandu University 
the front and other national pages which is out of observation for this study.

Biz News: Nepali language dailies mostly focus on domestic news to fill in their biz pages. English language newspapers give more priority to the global biz/financial news with TKP $28.3 \%$ and THT $21.3 \%$ followed by AP's $19.7 \%$ of their total biz coverage. The KP uses the least agency materials for biz news $(2.06 \%)$ (See Table 2 for the contribution of agency materials in total coverage of different news items).

International news: Except THT, none others used its own sources for international news during the study week. THT used materials from its correspondents in Delhi (India) and Islamabad (Pakistan). Though, KP and TKP have their bureau in Delhi, and Middle East (Doha, Qatar) none original materials appeared in the international page in the study week. Those bureaus mostly report about the events which are of domestic interest to Nepal and hence those stories find space in other pages. For the international coverage, they rely mostly on western giants AFP and AP. In one day (April 10) international page of Annapurna Post carried all the materials from AFP including pictures.

\begin{tabular}{|l|l|l|l|l|ll|ll|}
\hline $\begin{array}{l}\text { News } \\
\text { paper }\end{array}$ & $\begin{array}{l}\text { Biz } \\
\text { O }\end{array}$ & $\begin{array}{l}\text { Biz } \\
\text { A }\end{array}$ & $\begin{array}{l}\text { Int. } \\
\text { O }\end{array}$ & $\begin{array}{l}\text { Int. } \\
\text { A }\end{array}$ & $\begin{array}{l}\text { Ent. } \\
\text { O }\end{array}$ & $\begin{array}{l}\text { Ent. } \\
\text { A }\end{array}$ & $\begin{array}{l}\text { Sports } \\
\text { O }\end{array}$ & $\begin{array}{l}\text { Sports } \\
\text { A }\end{array}$ \\
\hline KP & 97.94 & 2.06 & 0.00 & 100.00 & 76.95 & 23.05 & 71.82 & 28.18 \\
\hline TKP & 71.65 & 28.35 & 0.00 & 100.00 & 43.50 & 56.50 & 28.56 & 71.44 \\
\hline AP & 80.33 & 19.67 & 0.00 & 100.00 & 74.94 & 25.06 & 74.96 & 25.04 \\
\hline THT & 78.61 & 21.39 & 26.79 & 73.21 & 39.34 & 60.66 & 76.55 & 23.45 \\
\hline
\end{tabular}

(Note: O stands for original and A stands for agency)

Table 2: Contribution of agency materials in total coverage of different news items

From the above discussions, we can conclude that newspapers use agency materials varying from $5 \%$ to $30 \%$ of their total contents. We have seen more reliance of English dailies on

Bodhi, 3 (1), 44-52. ISSN 2091-0479. (C) 2009 Kathmandu University 
agency materials than Nepali ones. The formers have also allocated more space for soft-touch news like entertainment and sports.

\section{A prospect for McJournalism?}

Based on Franklin's (2005) four underlying principles of McJournalism - efficiency, calculability, predictability and control - the following analysis provides some insight in to the trend of Nepali press towards McDonaldization.

In McDonaldization, efficiency is concerned with the way goods are produced, delivered and served to the consumers. Based on this principle, we can conclude that increased pagination and use of colors, big and colorful pictures, headlines and ready-to-consume news capsules are an implication of the newspapers trying to deliver their products more efficiently.

The optimum use of the international news in entertainment, sports and biz pages is similar to Franklin's concern for 'standardized and dehumanized form of journalism'; no concern for the esteemed watchdog role of journalism but to sell the newspapers. The optimized use of and dependence on the agency materials will kill the quality and diversity of the journalism. This trend fits into Calculability where, "the media delight in quantifying both their products and the time invested on particular tasks by their work force... Circulation is the key indicator of success" (Franklin, 2005, p. 144).

The Predictability of pages helps a reader foresee what type of stories will be carried out in the next day issue. We can outline a number of things related to standardization: all these newspapers have standardized pages i.e. Capital/metro, district/local, entertainment, biz/finance, sports, international etc and each day similar type of stories will fill in the space each issue.

Bodhi, 3 (1), 44-52. ISSN 2091-0479. (C) 2009 Kathmandu University 
What is sharply contrasting with the British press is the fourth principle of McJournalism - Control - lacking in Nepali press. Citing Ritzer Franklin says, "Control means the close and increasing control of both workers and consumers typically by the introduction of technology" (2005, p. 139). In his analysis of British newspapers, he states that they have introduced story count standard which defines how much time a scribe should spend on the type of the stories and how many sources s/he should use for that type of stories. Nepali broadsheet dailies have also introduced technology for the better and more efficient performance of the journalists. However, it is too early to say that technology has overtaken human efficiencies and also that Nepali newspapers will introduce story count system for their workforce.

In Franklin's study, all the four principles of McJournalism are clearly visible in the British press, "The local (British) press increasingly offers a standardized fare of McJournalism with similar editorial contents and formats" (p. 145). Nepali press is also witnessing some criticisms, nevertheless far less the level of the British press (Dixit, 2009). In comparison to the British Press on which Franklin bases his study, the process of 'Mcing' is not so prevalent and intense in Nepali press. Though they use agency materials, they have allocated a fair and more share for the national coverage and prioritized them.

The discussion so far lead us to the conclusion that broadsheet dailies of Nepal use 5-30\% standardized contents but it is too early to conclude that they have adopted McJournalism. Their contents are changing over time; recently, soft touch stories including sports and entertainment are getting more and more space, large part of which is received from the agencies. Nevertheless, Nepali press is not dehumanized as Franklin suggests.

I recommend the future researchers to look into the impact of public relations in news content or the use of PR agency materials by Nepali press. Though, Franklin's study focuses in

Bodhi, 3 (1), 44-52. ISSN 2091-0479. (C) 2009 Kathmandu University 
British press, it will also become interesting to have similar study in radio and television and also in other countries.

\section{Acknowledgements:}

This study was carried out as the partial fulfillment for RMP 05 Critical perspectives on Journalism, Public Relations and Advertising, Regional Masters' Program in Journalism, media and Communications, University of Dhaka, Bangladesh. I would like to thank course teacher Professor Dr. Robert Wallace-Vaaghan for his guidance and supervision.

\section{References}

Adhikary, N. M. (2002, December 11). Presenting international news. Space Time Today, p. 4.

Dixit, K. M. (2009). Tai chup, mai chup. Himal. April 14-28, 38.

Franklin, B. (2005). McJournalism: The local press and the McDonaldization thesis. In Allan, S. (Ed.) Journalism: Critical issues. Maidenhead: Open U Press.

Kshetri, I. D. (2006). Iraqi himsha Nepali sanchar madhyamma. Patrakarita. Jan-March, 2006: 12-15.

Bodhi, 3 (1), 44-52. ISSN 2091-0479. (C) 2009 Kathmandu University 